\title{
Induction of Anthracnose Disease Resistance on Chili Fruit by Treatment of Oligochitosan-Nanosilica Hybrid Material
}

\author{
Pham Dinh Dzung1,2, Le Thanh Hung1, Le Si Ngoc¹, Hoang Dac Hiet ${ }^{1}$, Bui Van Le³, \\ Nguyen Tien Thang', Dang Van Phu ${ }^{2,4}$, Nguyen Ngoc Duy ${ }^{4}$, Nguyen Quoc Hien ${ }^{*}$ \\ ${ }^{1}$ Research and Development Center for Hi-Tech Agriculture, Ho Chi Minh City, Vietnam \\ ${ }^{2}$ Graduate University of Science and Technology, Vietnam Academy of Science and Technology, Hanoi, Vietnam \\ ${ }^{3}$ University of Science, Vietnam National University, Ho Chi Minh City, Vietnam \\ ${ }^{4}$ Research and Development Center for Radiation Technology, Vietnam Atomic Energy Institute, Ho Chi Minh City, Vietnam \\ Email: *hien7240238@yahoo.com
}

How to cite this paper: Dzung, P.D., Hung, L.T., Ngoc, L.S., Hiet, H.D., Le, B.V., Thang, N.T., Van Phu, D., Duy, N.N. and Hien, N.Q. (2017) Induction of Anthracnose Disease Resistance on Chili Fruit by Treatment of Oligochitosan-Nanosilica Hybrid Material. Agricultural Sciences, 8, 1105-1113.

https://doi.org/10.4236/as.2017.810080

Received: September 21, 2017

Accepted: October 20, 2017

Published: October 23, 2017

Copyright (c) 2017 by authors and Scientific Research Publishing Inc. This work is licensed under the Creative Commons Attribution International License (CC BY 4.0).

http://creativecommons.org/licenses/by/4.0/

\section{c) (i) Open Access}

\begin{abstract}
Oligochitosan (OC) with molecular weight $\mathrm{Mw}$ of $5000 \mathrm{~g} / \mathrm{mol}$ was prepared by gamma Co-60 ray irradiation of chitosan solution. Nanosilica $\left(\mathrm{nSiO}_{2}\right)$ with the size of $10-30 \mathrm{~nm}$ was synthesized by calcination of acid treated rice husk. The mixture of $1 \% \mathrm{OC}-1 \% \mathrm{nSiO}_{2}$ was prepared by dispersion of $\mathrm{nSiO}_{2}$ in OC solution. The morphology of $\mathrm{nSiO}_{2}$ in the mixture of OC- $\mathrm{nSiO}_{2}$ was measured from images of transmission electron microscopy (TEM). The effect of foliar application of the mixture of $\mathrm{OC}-\mathrm{nSiO}_{2}$ on the induction of resistance against anthracnose disease caused by Colletotrichum gloeosporioides fungus on chili fruits was investigated. Results indicated that foliar application of OC- $\mathrm{nSiO}_{2}$ with the concentration of $60 \mathrm{mg} / \mathrm{l}-60 \mathrm{mg} / \mathrm{l}$ was found to be as the optimal treatment that reduced the disease severity on chili fruits to $22.2 \%$ compared with $90.0 \%$ of the control. Thus, $\mathrm{OC}-\mathrm{nSiO}_{2}$ hybrid material could be considered as an effective biotic elicitor to prevent anthracnose disease infection for chili fruits. Furthermore, the prepared $\mathrm{OC}-\mathrm{nSiO}_{2}$ hybrid material can also be used as an environmentally friendly agrochemical product for sustainable development of agriculture.
\end{abstract}

\section{Keywords}

Oligochitosan, Nanosilica, Chili Fruit, Colletotrichum gloeosporioides, Anthracnose

\section{Introduction}

Chitosan and oligochitosan (OC) have attracted considerable interest due to 
their many unique biological activities such as antioxidant activity [1], antimicrobial activity [2], plant growth promotion such as rice [3], coffee [4], soybean $[5], \ldots$ In addition, chitosan and OC also have elicitation effect to induce disease resistance in plants such as grapevine [6], potato [7], ... Moreover, OC was supposed as a plant vaccine that is similar to general animal vaccine [8]. The excessive use of chemical fertilizer and pesticide in agriculture may lead to adverse effects in food products and in the environment. Therefore, the recent trend in agriculture has been focused on organic and vertical farming not only addressing the rising concern for environmental issues but also accommodating the demands of food of increasing world population [9]. Organic farming is considered as a viable alternative in comparison to chemical-based agriculture [10]. Nanotechnology opens up a wide applicability in various fields like medicine, pharmaceutics, electronics and agriculture. Nanomaterials hold great promise of improved plant disease resistance, controlled release of agro-chemicals, enhanced plant growth, etc. [11]. According to [12], nanomaterials can be used as a magical tool for enhancing growth and improvement of agricultural production. Recently, the synergistic effect of a mixture of chitosan-silica induced resistance in tomato against bacterial wilt caused by Ralstonia solanacearum was reported for the first time [13]. Chili fruit is widely consumed mainly as a spice for food ingredients. World production of chilies in 2009 was estimated to be about 3 million tones [14]. The top-ten chili producing countries were India, China, Ethiopia, Myanmar, Mexico, Vietnam, Peru, Pakistan, Ghana and Bangladesh, and accounted for more than $85 \%$ of the world chili production in 2007 [15]. Anthracnose disease has been a real threat to chili (Capsicum spp.) production in the tropics and subtropics worldwide. Anthracnose is caused by a complex of Colletotrichum species, typically Colletotrichum capsici, Colletotrichum acutatum, and Colletotrichum gloeosporioides having been reported as significant pathogens in many countries including China, India, Brazil, Thailand and Vietnam, etc. [16]. Therefore, protection of chili fruits from infection of anthracnose disease is in high demand. Up to now, there are rare reports in the literature on the reduction of anthracnose disease on chili fruits using $\mathrm{OC}-\mathrm{nSiO}_{2}$ hybrid materials.

To contribute to the development of organic farming, in the present study, OC was prepared by gamma Co-60 irradiation degradation of chitosan in solution and $\mathrm{nSiO}_{2}$ was prepared from rice husk. The effect of foliar application of $\mathrm{OC}-\mathrm{nSiO}_{2}$ mixture on the induction of resistance against anthracnose disease caused by Colletotrichum gloeosporioides fungus on chili fruits was investigated.

\section{Materials and Methods}

\subsection{Preparation of Oligochitosan by $\gamma$-Irradiation}

Chitosan from shrimp shell with a degree of deacetylation (DDA\%) of 91.4\%; the weight average molecular weight $(\mathrm{Mw})$ of $44.5 \times 10^{3} \mathrm{~g} / \mathrm{mol}$ was supplied by a factory in Vietnam. OC with $\mathrm{Mw}$ of $5000 \mathrm{~g} / \mathrm{mol}$ was prepared by gamma Co-60 
ray irradiation degradation method as described in our previous paper [17] with some modifications. Briefly, chitosan (40 g) was dissolved in $800 \mathrm{ml}$ of $2 \%(\mathrm{w} / \mathrm{v})$ lactic acid solution, then $15 \mathrm{ml}$ of hydrogen peroxide $\left(30 \% \mathrm{H}_{2} \mathrm{O}_{2}\right)$ and $185 \mathrm{ml}$ water were added to prepare 1 liter of $4 \%(\mathrm{w} / \mathrm{v})$ chitosan solution containing $0.5 \% \mathrm{H}_{2} \mathrm{O}_{2}$. Then, the prepared chitosan solution was irradiated at ambient condition on gamma SVST Co-60/B irradiator at the VINAGAMMA Center with a dose of $21 \mathrm{kGy}$.

\subsection{Preparation of Nanosilica from Rice Husk}

$\mathrm{nSiO}_{2}$ with particles size of 10 - $30 \mathrm{~nm}$ was prepared from rice husk as described in our previous paper [18]. Briefly, raw rice husk was first rinsed with water to remove dusts, soluble substances, and other contaminants. It was then dried at $60^{\circ} \mathrm{C}$ in forced air oven (Yamato, DNF 410, Japan). $50 \mathrm{~g}$ of the dried rice husk was then treated with $500 \mathrm{ml}$ of $0.5 \mathrm{~N} \mathrm{HCl}$ at ambient temperature for $2 \mathrm{~h}$ by magnetic stirring. Then, it was decanted and thoroughly washed with distilled water until the rinse became free from acid. The treated-rice husk was subsequently dried in forced air oven until to dry and ground into fine powder. Finally, the rice husk powder was incinerated at $700^{\circ} \mathrm{C}$ for $2 \mathrm{~h}$ inside a programmable furnace (Nabertherm $\mathrm{GmbH}$, Germany) to obtain $\mathrm{nSiO}_{2}$.

\subsection{Preparation of Oligochitosan-Nanosilica Hybrid Material}

$10 \mathrm{~g}$ of $\mathrm{nSiO}_{2}$ were mixed with $77 \mathrm{ml}$ of $\mathrm{NaOH} 1 \mathrm{M}$ solution by string for $60 \mathrm{~min}$. Then $250 \mathrm{ml}$ of $4 \%$ OC solution and distilled water slowly added to prepare $1 \mathrm{li}$ ter of $1 \%$ OC- $1 \% \mathrm{nSiO}_{2}$. The mixture was then stirred for $4 \mathrm{~h}$ at room temperature. To increase the adsorption ability of $\mathrm{OC}$ on $\mathrm{nSiO}_{2}, \mathrm{pH}$ of the mixture was adjusted to $\sim 7.5$ [19]. The particle size of $\mathrm{nSiO}_{2}$ from rice husk and $\mathrm{nSiO}_{2}$ in the $\mathrm{OC}-\mathrm{nSiO}_{2}$ hybrid material was measured using transmission electron microscopy (TEM) images [18].

\subsection{Preparation of Colletotrichum gloeosporioides Fungal Suspension}

The C. gloeosporioides fungal strain was obtained from Microbial Laboratory of the Research and Development Center for Hi-Tech Agriculture. An inoculum of C. gloeosporioides was prepared by cultivating fungal colonies in Petri dishes on potato dextrose agar (PDA) medium at $30^{\circ} \mathrm{C}$ for ten days. Then, the fungal spores were harvested by flooding Petri dishes with sterile distilled water. The obtained suspension of fungal spores was then adjusted to $10^{4}$ spores $/ \mathrm{ml}$ with distilled water [20].

\subsection{Experimental Design}

The 60 - 65 day-old-chili plants (Capsicum frutescens L.) with young green fruits were used for the study. The experiment was conducted in the greenhouse of Hi-Tech Agriculture Center, $\mathrm{Cu} \mathrm{Chi}$, Ho Chi Minh City, at $30^{\circ} \mathrm{C} \pm 2{ }^{\circ} \mathrm{C}$ and 
RH of $60 \% \pm 2 \%$. The experimental treatments were arranged in a randomized complete block design with five treatments namely: control (water), 20 - 20, 40 40, 60 - 60 and $80 \mathrm{mg} / \mathrm{l}-80 \mathrm{mg} / \mathrm{l}$ of $\mathrm{OC}-\mathrm{nSiO}_{2}$. Particularly, 1 liter of $1 \%$ OC $1 \% \mathrm{nSiO}_{2}$ was diluted with water up to the volume of 500, 250, 167, and $125 \mathrm{li}$ ters for preparation of foliar spaying solution of $20-20,40-40,60-60$ and 80 $\mathrm{mg} / \mathrm{l}-80 \mathrm{mg} / \mathrm{l}$ of $\mathrm{OC}-\mathrm{nSiO}_{2}$, respectively. Each treatment consisted of three replications with 10 plants/replication.

\subsection{Foliar Application of $\mathrm{OC}-\mathrm{nSiO}_{2}$ on Chili Plants and Fungal Inoculation on Chili Fruits}

The chili plants were sprayed three times with a duration of one time per week. After $24 \mathrm{~h}$ of the third spaying, the chili fruits were caused lesions as follows: 50 fruits/chili plant were randomly selected to create lesion by using a needle with a diameter of $0.6 \mathrm{~mm}$ to pierce through the fruits. Then, the injury fruits were inoculated with $C$. gloeosporioides fungus by spaying fungal spore suspension of $10^{4}$ spores $/ \mathrm{ml}$.

\subsection{Assessment of Disease Severity}

After 7 days of fungal inoculation, the disease severity (DS) was then recorded and calculated as follows [21]:

DS $(\%)=100 \times($ number of infected fruits)/(total number of inoculated fruits)

All data were statistically analyzed by analysis of variance (ANOVA) according to the experimental design and Least Significant Difference (LSD) at 5\% probability level was utilized to compare the different means.

\section{Results}

\subsection{Morphology of $\mathrm{nSiO}_{2}$}

TEM images of $\mathrm{nSiO}_{2}$ and $\mathrm{nSiO}_{2}$ in the mixture of $1 \% \mathrm{OC}-1 \% \mathrm{nSiO}_{2}$ were presented in Figure 1. The size of $\mathrm{nSiO}_{2}$ synthesized from rice husk was of $10-30 \mathrm{~nm}$ in

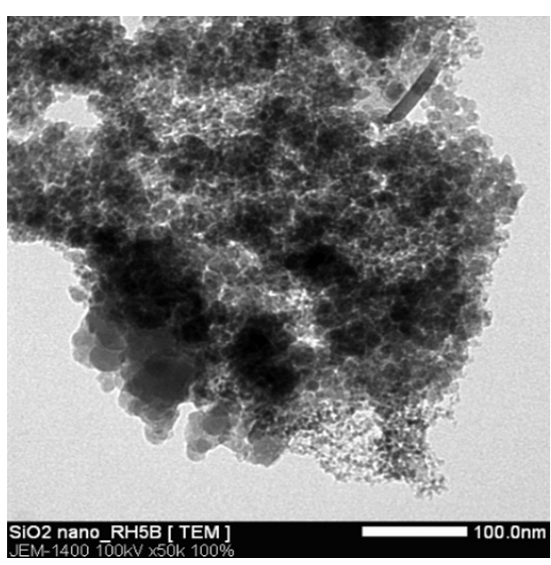

(a)

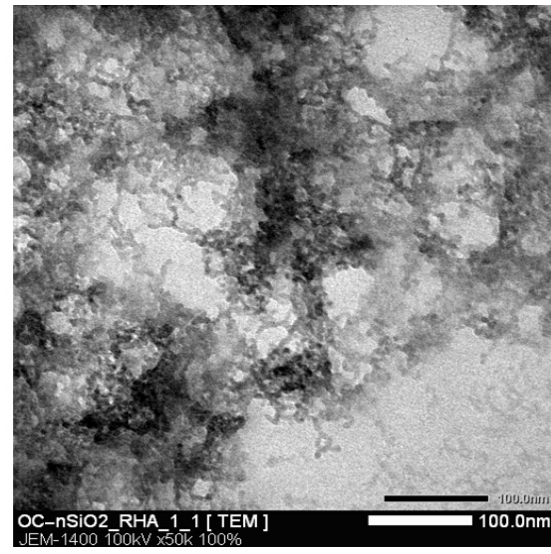

(b)

Figure 1. TEM images of $\mathrm{nSiO}_{2}$ (a) and $\mathrm{nSiO}_{2}$ in mixture of $1 \% \mathrm{OC}-1 \% \mathrm{nSiO}_{2}$ (b). 
Figure 1(a) and the size of $\mathrm{nSiO}_{2}$ in the $\mathrm{OC}-\mathrm{nSiO}_{2}$ mixture in Figure 1(b) was observed to be rather smaller to that of original $\mathrm{nSiO}_{2}$.

The schematic interaction of $\mathrm{OC}$ with $\mathrm{nSiO}_{2}$ was illustrated in Figure 2. When $\mathrm{nSiO}_{2}$ was mixed with $\mathrm{OC}$ solution, the bonding of $-\mathrm{Si}-\mathrm{O}-\mathrm{C}-,-\mathrm{Si}-\mathrm{O}-\mathrm{H}_{2} \mathrm{~N}-$, and $-\mathrm{Si}-\mathrm{OH}$ occurred in the mixture of $\mathrm{OC}-\mathrm{nSiO}_{2}$.

\subsection{Anthracnose Disease Severity on Chili Fruits}

Photographs of chili plants in greenhouse and symptom of anthracnose disease with concave lesion stains in slightly brown color on chili fruits caused by $C$. gloeosporioides fungus were presented in Figure 3.

The disease severity of chili fruits treated with $\mathrm{OC}-\mathrm{nSiO}{ }_{2}$ with different concentration and inoculated with $C$. gloeosporioides fungal spores was presented in Table 1.

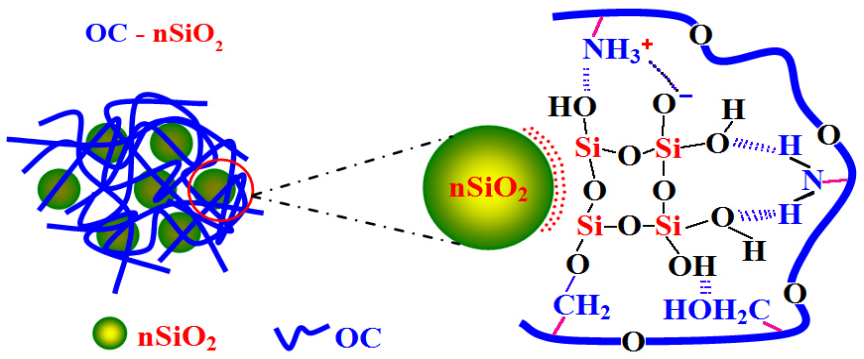

Figure 2. Schematic illustration of interactions between $\mathrm{OC}$ and $\mathrm{nSiO}_{2}$.

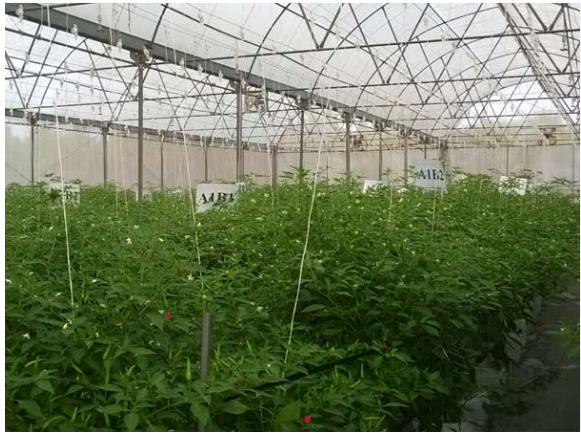

(a)

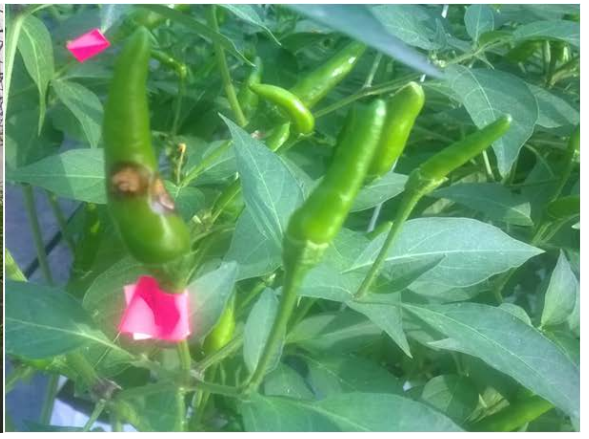

(b)

Figure 3. Photographs of chili plants in greenhouse (a) and symptom of anthracnose disease on chili fruit caused by $C$. gloeosporioides fungus (b).

Table 1. Disease severity of chili fruits inoculated with $C$. gloeosporioides fungal spores.

\begin{tabular}{cc}
\hline OC-nSiO $_{2}, \mathrm{mg} / \mathrm{L}$ & DS, \% \\
\hline Control (water) & $90.0 \pm 11.5^{\mathrm{d}}$ \\
$20-20$ & $62.2 \pm 5.1^{\mathrm{c}}$ \\
$40-40$ & $35.6 \pm 1.9^{\mathrm{b}}$ \\
$60-60$ & $22.2 \pm 1.9^{\mathrm{a}}$ \\
$80-80$ & $33.3 \pm 8.8^{\mathrm{b}}$
\end{tabular}

Different letters in the same column indicate significant differences at $P \leq 0.05$. 


\section{Discussion}

The greatest challenge in the application of OC for plant protection lies in the development of efficient methods for large-scale production of OC [22]. For this aspect, the production of OC by gamma Co-60 irradiation method can be favorably applied on large-scale [17] [23].

TEM image in Figure 1(b) indicated that the $\mathrm{nSiO}_{2}$ morphology was almost maintained as the original $\mathrm{nSiO}_{2}$. However, some small parts were aggregated that may be presumed due to the interaction of $\mathrm{nSiO}_{2}$ with OC. Also, $\mathrm{nSiO}_{2}$ may be changed to $\mathrm{Si}(\mathrm{OH})_{4}$ in slightly basic medium $\mathrm{pH} \sim 7.5$ [19]. As our observation, OC solution, unlike chitosan, is not precipitated in neutral and/or slightly basic medium. As can be observed in Figure 2 that the bonding of -Si-O-C-, $-\mathrm{Si}-\mathrm{O}-\mathrm{H}_{2} \mathrm{~N}-$, and $-\mathrm{Si}-\mathrm{OH}$ between $\mathrm{OC}$ and $\mathrm{nSiO}_{2}$ was formed [21] and owing to these bonds, the colloidal mixture of $\mathrm{OC}-\mathrm{nSiO}_{2}$ was in good stability during storage. Accordingly, the bonding of chitosan and $\mathrm{nSiO}_{2}$ in the mixture of chitosan- $\mathrm{nSiO}_{2}[24]$ was almost the same as in the mixture of $\mathrm{OC}-\mathrm{nSiO}_{2}$.

Results in Table 1 indicated that foliar application of $\mathrm{OC}-\mathrm{nSiO}_{2}$ induced significantly anthracnose disease resistance caused by $C$. gloeosporioides fungus on chili fruits. Among four treatments with different concentration of $\mathrm{OC}-\mathrm{nSiO}_{2}$, the treatment with a concentration of $60 \mathrm{mg} / \mathrm{l}-60 \mathrm{mg} / \mathrm{l}$ was found to act the highest effect in reduction of anthracnose disease on chili fruits. In particular, the disease severity of the treatment of $60 \mathrm{mg} / \mathrm{l}-60 \mathrm{mg} / \mathrm{l} \mathrm{OC}-\mathrm{nSiO}_{2}$ was reduced to $22.2 \%$ compared to $90.0 \%$ of the control (water). It was reported that the bacterial wilt incidence on tomato plants was also significantly reduced by the treatment with chitosan-silicon mixture [13]. In particular, the bacterial wilt incidence was of $\sim 20 \%$ for tomato plants treated with chitosan-silicon compared to $\sim 80 \%$ of the control (without chitosan and silicon, inoculation with $R$. solanacearum). Recently, foliar application of $\mathrm{OC}-\mathrm{nSiO}_{2}$ with a concentration of 50 $\mathrm{mg} / \mathrm{l}-50 \mathrm{mg} / \mathrm{l}$ increased soybean seed yield of $17 \%$ compared to control (water) [23]. Thus, it can be expected that foliar application of OC- $\mathrm{nSiO}_{2}$ is not only to induce disease infection resistance but also to increase chili fruit yield. Further study on the effect of $\mathrm{OC}-\mathrm{nSiO}_{2}$ treatment on the enhancement of chili fruit yield should be carried out. Moreover, the nanomaterials, owing to their increased contact surface area, might have toxic effects that are not apparent in the bulk materials especially in the open agricultural ecosystem [24]. Therefore, the selection of nanomaterial for application in the field may be critically desirable as materials, which are non-toxic, biocompatible and biodegradable [25]. In this issue, it was reported that different form of synthetic amorphous silica has been used in a wide variety of industrial and consumer applications including food, cosmetics and pharmaceutical products for many decades, and no environmental or health risks have been associated with these materials including $\mathrm{nSiO}_{2}$ [26]. Therefore, the as-prepared $\mathrm{OC}-\mathrm{nSiO}{ }_{2}$ hybrid material can be considered as a safe product to human health and environment. 


\section{Conclusion}

The method of gamma Co-60 ray irradiation degradation of chitosan in solution to prepare oligochitosan can be favorably applied on large scale. Nanosilica, a value-added product was appropriately synthesized from rice husk, an abundant agriculture waste. Foliar application of $\mathrm{OC}-\mathrm{nSiO}_{2}$ on chili plant resulted in significant induction of anthracnose disease resistance caused by $C$. gloeosporioides fungus on chili fruits. Thus, the $\mathrm{OC}-\mathrm{nSiO}_{2}$ hybrid material originated from natural resources can be potentially used to replace hazardous agrochemicals for sustainable agricultural production.

\section{Acknowledgements}

This research is funded by Vietnam National Foundation for Science and Technology Development (NAFOSTED) under grant number “106-NN.03-2015.84”.

\section{References}

[1] Kim, K.W. and Thomas, R.L. (2007) Antioxidative Activity of Chitosans with Varying Molecular Weights. Food Chemistry, 101, 308-313. https://doi.org/10.1016/j.foodchem.2006.01.038

[2] Zheng, L.Y. and Zhu, J.F. (2003) Study on Antimicrobial Activity of Chitosan with Different Molecular Weights. Carbohydrate Polymers, 54, 527-530. https://doi.org/10.1016/j.carbpol.2003.07.009

[3] Chamnanmanoontham, N., Pongprayoon, W., Pichayangkura, R., Roytrakul, S. and Chadchawan, S. (2015) Chitosan Enhances Rice Seedling Growth via Gene Expression Network between Nucleus and Chloroplast. Plant Growth Regulation, 75, 101-114. https://doi.org/10.1007/s10725-014-9935-7

[4] Dzung, N.A., Khanh, V.T.P. and Dzung, T.T. (2011) Research on Impact of Chitosan Oligomers on Biophysical Characteristics, Growth, Development and Drought Resistance of Coffee. Carbohydrate Polymers, 84, 751-755. https://doi.org/10.1016/j.carbpol.2010.07.066

[5] Luan, L.Q., Nagasawa, N., Tamada, M. and Nakanishi, T.M. (2006) Enhancement of Plant Growth Activity of Irradiated Chitosan by Molecular Weight Fractionation. Radioisotopes, 55, 21-27. https://doi.org/10.3769/radioisotopes.55.21

[6] Aziz, A., Trotel-Aziz, P., Dhuicq, L., Jeandet, P., Couderchet, M., et al. (2006) Chitosan Oligomers and Copper Sulfate Induce Grapevine Defense Reactions and Resistance to Gray Mold and Downy Mildew. Phytopathology, 96, 1188-1194.

https://doi.org/10.1094/PHYTO-96-1188

[7] Vasyukova, N.I., Zinov'eva, S.V., Il'inskaya, L.I., Perekhod, E.A., Chalenko, G.I., et al. (2001) Modulation of Plant Resistance to Diseases by Water-Soluble Chitosan. Applied Biochemistry and Microbiology, 37, 103-109. https://doi.org/10.1023/A:1002865029994

[8] Yin, H., Zhao, X. and Du, Y. (2010) Oligochitosan: A Plant Disease Vaccine: A Review. Carbohydrate Polymers, 82, 1-8. https://doi.org/10.1016/j.carbpol.2010.03.066

[9] Garg, A. and Balodi, R. (2014) Recent Trends in Agriculture: Vertical Farming and Organic Farming. Advances in Plants and Agriculture Research, 1, Article ID: 00023. https://doi.org/10.15406/apar.2014.01.00023 
[10] Stockdale, E.A., Lampkin, N.H., Hovi, M., Keatinge, R., Lennartsson, E.K.M., et al. (2001) Agronomic and Environmental Implications of Organic Farming Systems. Advances in Agronomy, 70, 263-327. https://doi.org/10.1016/S0065-2113(01)70007-7

[11] Huang, S., Wang, L., Liu, L., Hou, Y. and Li, L. (2015) Nanotechnology in Agriculture, Livestock, and Aquaculture in China. A Review. Agronomy for Sustainable Development, 35, 369-400. https://doi.org/10.1007/s13593-014-0274-x

[12] Taha, R.A. (2016) Nanotechnology and Its Application in Agriculture. Advances in Plants and Agriculture Research, 3, Article ID: 00089. https://doi.org/10.15406/apar.2016.03.00089

[13] Kiirika, L.M., Stahl, F. and Wydra, K. (2013) Phenotypic and Molecular Characterization of Resistance Induction by Single and Combined Application of Chitosan and Silicon in Tomato against Ralstonia solanacearum. Physiological and Molecular Plant Pathology, 81, 1-12. https://doi.org/10.1016/j.pmpp.2012.11.002

[14] Tiwari, R.K. (n.d.) Post Harvest Profile of Chili. http://agmarknet.gov.in/Others/preface-chhilli.pdf

[15] Huq, A.S.M.A. and Arshad, F.M. (2010) Technical Efficiency of Chili Production. American Journal of Applied Sciences, 7, 185-190. https://doi.org/10.3844/ajassp.2010.185.190

[16] Mahasuk, P., Khumpeng, N., Wasee, S., Taylor, P.W.J. and Mongkolporn, O. (2009) Inheritance of Resistance to Anthracnose (Colletotricum casici) at Seedling and Fruiting Stages in Chili Pepper (Capsicum spp.). Plant Breeding, 128, 701-706. https://doi.org/10.1111/j.1439-0523.2008.01615.x

[17] Duy, N.N., Phu, D.V., Anh, N.T. and Hien, N.Q. (2011) Synergistic Degradation to Prepare Oligochitosan by $\gamma$-Irradiation of Chitosan Solution in the Presence of Hydrogen Peroxide. Radiation Physics and Chemistry, 80, 848-853. https://doi.org/10.1016/j.radphyschem.2011.03.012

[18] Dzung, P.D, Ngoc, L.S., Thuy, N.N., Truc, L.T.M., Le, B.V., et al. (2016) Effect of Nanosilica from Rice Husk on the Growth Enhancement of Chili Plant (Casicum frutescens L.). Journal of Science and Technology, 54, 607-613.

[19] Tiraferri A., Maroni, P., Rodríguez, D.C. and Borkovec, M. (2014) Mechanism of Chitosan Adsorption on Silica from Aqueous Solutions. Langmuir, 30, 4980-4988. https://doi.org/10.1021/la500680g

[20] Somapala, K.S., Weerahewa, H.L.D. and Thrikawala, S. (2016) Enhanced Resistance against Anthracnose Disease in Chili Pepper (Capsicum annuum L.) by Soil Application of Potassium. International Journal of Agriculture, Forestry and Plantation, 2, 35-39. http://digital.lib.ou.ac.lk/docs/bitstream/701300122/1227/1/KLIAFP2_39.pdf

[21] Ahmad, A. and Ashraf, Y. (2016) In Vitro and In Vivo Management of Alternaria Leaf Spot of Brassica campestris L. Journal of Plant Pathology \& Microbiology, 7, Article ID: 1000365. https://doi.org/10.4172/2157-7471.1000365

[22] Das, S.N., Madhuprakash, J., Sarma, P.V.S.R.N., Purushotham, P., Suma, K., et al. (2015) Biotechnological Approaches for Field Applications of Chitooligosaccharides (COS) to Induce Innate Immunity in Plants. Critical Reviews in Biotechnology, 35, 29-43. https://doi.org/10.4172/2157-7471.1000365

[23] Phu, D.V., Du, B.D., Tuan, L.N.A., Tam, H.V. and Hien, N.Q. (2017) Preparation and Foliar Application of Oligochitosan-Nanosilica on the Enhancement of Soybean Seed Yield. International Journal of Environment, Agriculture and Biotech- 
nology, 2, 421-428. https://doi.org/10.22161/ijeab/2.1.53

[24] Sumarni, W., Iswari, R.S., Marwoto, P. and Rahayu, E.F. (2016) Physical Characteristics of Chitosan-Silica Composite of Rice Husk Ash. IOP Conference Series: Materials Science and Engineering, 107, Article ID: 012039.

https://doi.org/10.1088/1757-899X/107/1/012039

[25] Ghormade, V., Deshpande, M.V. and Paknikar, K.M. (2011) Perspective for Nano-Biotechnology Enabled Protection and Nutrition of Plants. Biotechnology Advances, 29, 792-803. https://doi.org/10.1016/j.biotechadv.2011.06.007

[26] Fruijtier-Pölloth, C. (2012) The Toxicological Mode of Action and the Safety of Synthetic Amorphous Silica-A Nanostructured Material. Toxicology, 294, 61-79. https://doi.org/10.1016/j.tox.2012.02.001 